\title{
Synthesis of Novel Cinnamides and a Bis Cinnamate Bearing 1,2,3-Triazole Functionalities with Antiproliferative and Antimetastatic Activities on Melanoma Cells
}

\author{
Fabíola S. Santos, ${ }^{\#, a}$ Juliana A. do Vale, ${ }^{\#, b}$ Lucas S. Santos, ${ }^{a}$ Talita B. Gontijo, ${ }^{a}$ \\ Graziela D. A. Lima, ${ }^{b}$ Leandro L. de Oliveira, ${ }^{\circledR b}$ Mariana Machado-Neves, ${ }^{b}$ \\ Róbson R. Teixeira ${ }^{\circledR c}$ and Rossimiriam P. de Freitas ${ }^{\circledR} *, a$ \\ ${ }^{a}$ Laboratório de Síntese Orgânica (LABSINTO), Departamento de Química, \\ Universidade Federal de Minas Gerais (UFMG), 31270-901 Belo Horizonte-MG, Brazil \\ ${ }^{b}$ Departamento de Biologia Geral, Universidade Federal de Viçosa (UFV), 36570-900 Viçosa-MG, Brazil

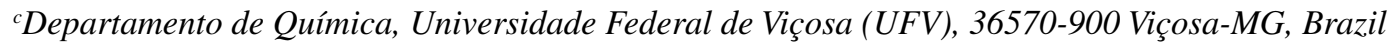

The present investigation describes the synthesis of novel cinnamides and a bis cinnamate bearing 1,2,3-triazole functionalities and investigation of their antiproliferative and antimetastatic effects on melanoma cells. The necessity for the development of new chemotherapeutic agents for melanoma treatment motivated this work. Sixteen derivatives were obtained with yields ranging from $23-81 \%$ and fully characterized by spectroscopic $\left({ }^{1} \mathrm{H}\right.$ and ${ }^{13} \mathrm{C}$ nuclear magnetic resonance, infrared) and spectrometric high resolution mass spectrometry (HRMS) techniques. The derivatives were in vitro evaluated against B16-F10 murine melanoma cell line. The most effective compound (a bis cinnamate) (6b) reduced the melanoma cell viability, generated cell cycle arrest, and influenced the metastatic behavior of melanoma cells by decreasing migration, invasion, and colony formation. Based on these findings, it is believed that compound $\mathbf{6 b}$ may represent an interesting scaffold to be explored toward the development of new antimelanoma agents.

Keywords: cinnamides, cinnamates, cinnamic acid, 1,2,3-triazoles, B16-F10 cell line

\section{Introduction}

Melanoma is the most serious type of skin cancer. ${ }^{1,2}$ It is originated from uncontrolled growth of melanocytes that are dendritic-like cells responsible for skin pigmentation. ${ }^{3,4}$ Melanoma accounts for the highest number of skin cancer deaths worldwide, and its incidence rate is increasing over the last years. ${ }^{5-7}$ In 2020 , new melanoma cases in the United States were estimated to be about 100,350 with 6,850 deaths, whereas in Brazil approximately 8,450 new cases were projected..$^{5,8}$

Genetic mutations, excessive ultraviolet radiation exposure, severe sunburn, outdoor training, advanced age, and gender are relevant factors related to melanoma susceptibility. ${ }^{2,9}$ Additionally, melanoma has a high tendency to spread to other parts of the body. This metastatic behavior increases the challenge to treat this disease. Altogether, these facts evidence the melanoma severity. ${ }^{10-13}$

*e-mail: rossimiriam@ufmg.br

\#These authors contributed equally to this work.
Surgical resection is the main option available for patients with early stage of melanoma. Once present the metastatic form, systemic treatment is the mainstay of therapy, which includes radiotherapy, cytotoxic chemotherapy, immunotherapy, and targeted therapies. ${ }^{5,12}$ Particularly, the chemotherapy has been using several compounds over the years, such as dacarbazine, dabrafenibe, binimetinib, vemurafenib, encorafenib, trametinib, and cobimetinib. ${ }^{12,14-18}$ However, these drugs still exhibit important side effects and low efficacy when used individually. ${ }^{19}$ These facts justify the need for the development of new chemotherapeutic agents to be used in the treatment of metastatic melanoma.

In the search for new antimelanoma agents, natural products have been an extraordinary source of compounds with great chemical variability and biological activities, ${ }^{20-23}$ including antimelanoma. ${ }^{24,25}$ Newman and $\mathrm{Cragg}^{26}$ reported that $83 \%$ of anticancer drugs approved between 1981 and 2014 were either natural products per se or were based thereon. For instance, paclitaxel is an antimelanoma drug from natural sources derived from the bark of the Pacific yew tree (Taxus brevifolia). ${ }^{12}$ 
Cinnamic acid and its derivatives are natural plantderived compounds that present antitumor and other biological activities. They have been used as templates for designing and arriving at newly compounds with antitumor activities. ${ }^{27,28}$ Our research group reported the preparation of a series of twenty-six cinnamic acid derivatives resulting from the connection of cinnamic acid with 1,2,3-triazole functionalities. ${ }^{28}$ In the latter, B16-F10 cell line was used in in vitro assays to evaluate the antimelanoma activity of these compounds. The most potent cinnamate 3-(1-benzyl-1H-1,2,3-triazol-4-yl)propyl showed significant antiproliferative and antimetastatic activities against B16-F10 cells by interacting with matrix metalloproteinase 9 (MMP-9) and MMP-2, which are directly involved in melanoma progression. ${ }^{28}$ Indeed, compounds bearing the 1,2,3-triazole ring present a variety of therapeutic effects including antitumor activity. ${ }^{29,30}$ Due to this fact, this fragment is relevant to medicinal chemistry ${ }^{29}$ and used as pharmacophore. ${ }^{31}$ Likewise, cinnamides are cinnamic acid derivatives found in nature. ${ }^{32-34}$ Also known as cinnamamides and cinnamic acid amides, they present a broad range of pharmacological activities, which include antitubercular, anti-trypanosomal, anti-diabetic, anti-microbial, antiviral, anti-inflammatory, anti-malarial, nervous disorders, and antitumor. ${ }^{35}$

In our ongoing efforts to find useful compounds for the treatment of melanoma, ${ }^{28,36,37}$ and considering antitumor activity linked to cinnamides, cinnamates, and compounds displaying the 1,2,3-triazole functionality, it is herein described the synthesis and antimelanoma evaluation of a series novel cinnamides and a bis cinnamate bearing 1,2,3-triazole fragment(s).

\section{Results and Discussion}

\section{Synthesis}

The steps involved in the synthesis of cinnamides 3a-3n are outlined in Scheme 1.

The amide 2 was prepared via the reaction of cinnamic acid (1) and propargyl amine. ${ }^{38}$ The reaction was carried out in the presence of EDAC (hydrochloride of 1-ethyl3-(3'dimethylaminopropyl)carbodiimide) which promoted coupling of the acid and the amine in good yield (86\%). Then, the copper(I)-catalyzed alkyne-azide cycloaddition (CuAAC) reactions ${ }^{39-42}$ between 2 and several aromatic azides afforded the cinnamides $\mathbf{3 a}-\mathbf{3 n}$ with yields ranging from $30-81 \%$.

The synthesis of cinnamides 3a-3n required the preparation of twelve benzyl azides and two 3 -azidocoumarins. The benzyl azides were prepared via conversion of benzyl alcohols to the corresponding ester sulfonates, followed by the treatment of these esters with sodium azide, as previously reported..$^{43}$ The 3 -azidocoumarins, in turn, were obtained from the substituted salicylaldehyde and $N$-acetylglycine or ethyl nitroacetate through routes involving two and three steps, according to methodology previously described. ${ }^{44}$

One aspect deserves comment at this point. In our previous work, we synthesized a series of cinnamates bearing 1,2,3-triazole functionalities. ${ }^{28}$ Indeed, these cinnamates presented different degrees of efficiency against the melanoma B16-F10 cell line. Their efficiency depended on the benzyl groups present in the triazole functionality of the cinnamates. These benzyl groups, in

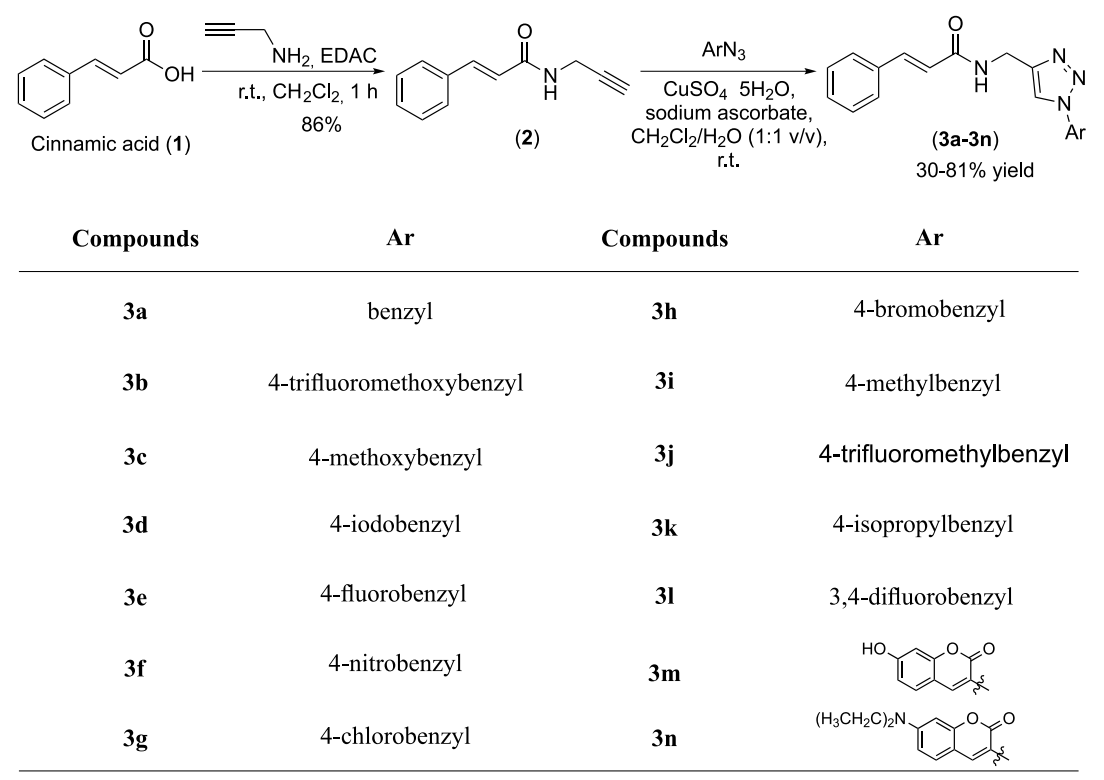

Scheme 1. Synthesis of cinnamides 3a-3n. 
turn, came from the benzyl azides. Herein, benzyl azides were also used in the preparation of cinnamides in order to make possible a comparison between the antimelanoma activity of cinnamates previously published by us ${ }^{28}$ and the cinnamides herein investigated.

The structures of the new cinnamides $\mathbf{3 a - 3 n}$ were confirmed based on infrared (IR), ${ }^{1} \mathrm{H},{ }^{13} \mathrm{C}$ nuclear magnetic resonance (NMR) spectroscopic techniques and highresolution mass spectrometry (HRMS) analyses. The IR spectrum showed bands for the $\mathrm{N}-\mathrm{H}$ stretching within the $3230-3279 \mathrm{~cm}^{-1}$ range. Also, carbonyl stretching vibrations for the amide groups were noticed within the interval $1615-1670 \mathrm{~cm}^{-1}$. In the ${ }^{1} \mathrm{H} \mathrm{NMR}$, the coupling constants for the hydrogens of aliphatic double bonds were approximately equal to $16 \mathrm{~Hz}$, which confirms the trans stereochemistry of these bonds. The singlet typically observed around 8 ppm confirmed the presence of the 1,2,3-triazole functionality in the structures of the cinnamides. The presence of the amide group was also confirmed by ${ }^{13} \mathrm{C} \mathrm{NMR}$; the signals for the carbonyl groups of this functionality were noticed within the 164.8-168.4 ppm range. The molecular formulas of the cinnamides were confirmed via HRMS analyses.

Our research group has demonstrated important cytotoxic effects for symmetrical 1,4-disubstituted bis-1,2,3-triazoles. ${ }^{45}$ Based on that, we decided to prepare the bis cinnamide $\mathbf{6 a}$ and cinnamate $\mathbf{6 b}$ as shown in Scheme 2 . The synthesis of bis azide 4 has been previously reported. ${ }^{45}$

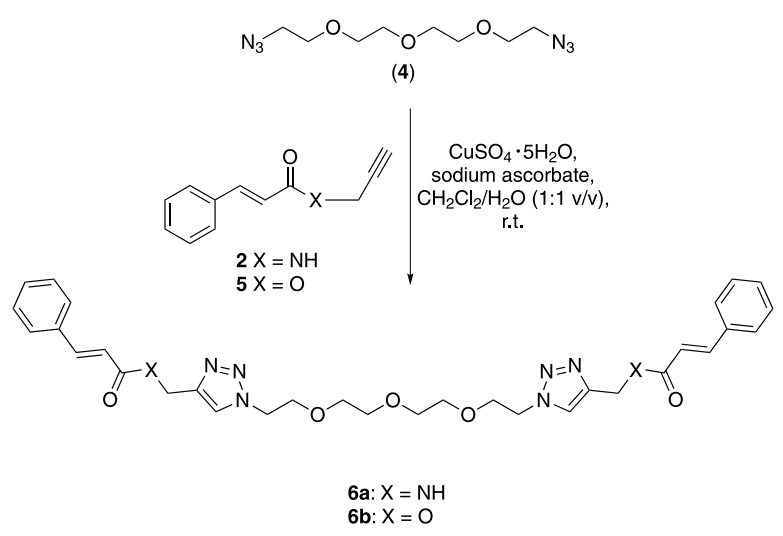

Scheme 2. Preparation of compounds $6 \mathbf{a}$ and $\mathbf{6 b}$.

The compound $\mathbf{6 b}$ was prepared to compare the biological response of the bis ester cinnamate in relation to bis cinnamide $\mathbf{6 a}$ (Scheme 2). The ester $\mathbf{5}$ was prepared via condensation of cinammic acid (1) and propargyl alcohol promoted by EDAC as previously published by us. ${ }^{28}$

The spectroscopic data that confirmed the structures of cinnamic acid derivatives $\mathbf{3 a - 3 n}, \mathbf{6} \mathbf{a}$ and $\mathbf{6 b}$ are available in the Supplementary Information (SI) section.
Effect of compounds $\mathbf{3 a - 3 n , 6 a}$ and $\mathbf{6 b}$ on the viability and cytotoxicity of B16-F10 cells

In the current study, compounds $\mathbf{3 c}, \mathbf{3 e}, \mathbf{3 f}, \mathbf{3 j}$, and 6b reduced significantly the viability of metastatic B16-F10 cells at $100 \mu \mathrm{M}$ (Figure 1). Therefore, these five compounds were evaluated for the half-maximal inhibitory concentration $\left(\mathrm{IC}_{50}\right)$. While compound $3 \mathbf{c}$ presents an electron-donating group $\left(-\mathrm{OCH}_{3}\right)$ at the para position of the benzyl group, the compounds $\mathbf{3 e}(-\mathrm{F}), \mathbf{3 f}$ $\left(-\mathrm{NO}_{2}\right)$, and $\mathbf{3 j}\left(-\mathrm{CF}_{3}\right)$ have electron withdrawing ones. Besides, compound $\mathbf{6 b}$ is a bis 1,2,3-triazole, a class of compounds endowed with antitumor activity. ${ }^{45}$ While the similar 1,2,3-triazolic cinnamate with a $p$-methoxy benzyl group, at the $100.0 \mu \mathrm{M}$, was inactive against B16-F10 cell line ${ }^{28}$ the cinnamide $3 \mathbf{c}$ could reduce cell viability in approximately $40 \%$. On the contrary, the 1,2,3-triazolic cinnamates possessing the $p$-fluoro benzyl, $p$-nitro benzyl, and $p$-trifluoromethyl benzyl groups were equipotent to the cinnamides $\mathbf{3 e}, \mathbf{3 f}$, and $\mathbf{3 j}$ counterparts.

Although metastatic B16-F10 is known to be very resistant to antitumor agents, ${ }^{46}$ the compounds $\mathbf{3 j}$ and 6b displayed superior cytotoxic activity $\left(\mathrm{IC}_{50}\right.$ values of 153.4 and $57.66 \mu \mathrm{M}$, respectively) than cinnamic acid (>200.0 $\mu \mathrm{M}$, data not shown). In contrast, the cinnamides 3c, 3e, and 3f showed $\mathrm{IC}_{50}$ values greater than $200.0 \mu \mathrm{M}$. The cytotoxic effects presented by compounds $\mathbf{3 j}$ and $\mathbf{6 b}$ corroborate with previous studies, in which cinnamic acid derivatives also have presented relevant cytotoxic effects on the metastatic melanoma cell line. ${ }^{28,47}$ In the study of Sova et al.$^{47}$ cytotoxic effects of representative cinnamic acid esters and amides were seen in different types of cancer in vitro, including melanoma. Besides that, the compounds tested showed selectivity of these cytotoxic effects on the malignant cell lines versus the peripheral blood mononuclear cells. ${ }^{47}$

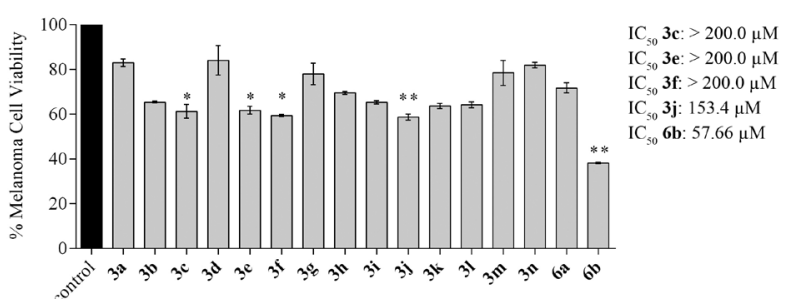

Figure 1. Effect of compounds $3 \mathbf{a}-\mathbf{3 n}, \mathbf{6 a}$ and $\mathbf{6 b}$ on cell viability of melanoma cells. B16-F10 metastatic melanoma was treated with $100.0 \mu \mathrm{M}$ of each compound for $48 \mathrm{~h}$. Each bar shows the mean of percentage of survival of melanoma cells determined by MTT (3-(4,5-dimethylthiazol2-yl)-2,5-diphenyltetrazolium bromide) assay. The compounds that showed statistical difference in relation to the control were selected for $\mathrm{IC}_{50}$ evaluation. Data expressed as the mean \pm SEM (standard error of the mean). $* p<0.05$ and $* * p<0.01$ versus control (DMSO, dimethyl sulfoxide, $0.4 \% \mathrm{v} / \mathrm{v}$ ) by one-way ANOVA and Dunn's post-hoc test. 
Effect of the compounds $\mathbf{3 c}, \mathbf{3 e}, \mathbf{3 f}, \mathbf{3} \mathbf{j}$, and $\mathbf{6 b}$ on nontumoral cell viability

The cytotoxicity of compounds in non-tumoral cells was also evaluated by means of Vero fibroblast-like kidney cells treated with the compounds $\mathbf{3 c}, \mathbf{3 e}, \mathbf{3 f}, \mathbf{3 j}$, and $\mathbf{6 b}$. Vero cells showed sensitivity for the compounds $3 \mathbf{e}, \mathbf{3 f}$, and $\mathbf{6 b}$ at $100.0 \mu \mathrm{M}$, being $\mathbf{3 e}$ the most cytotoxic (Figure 2).

This assay is relevant to compare the effect of compounds on non-tumoral cells, once that novel cancer chemotherapy relies on the selection of malignant-cell specific drugs and non-toxic to normal cells. ${ }^{48}$ Meantime, cytotoxic chemotherapy can kill more cancer cells than normal tissue, as seen in cytotoxic drugs used to treat cancer. ${ }^{49}$ It was the case of the results observed for the compound $\mathbf{6 b}$, which presented certain cytotoxicity in non-tumor cells, but it was the most effective in B16-F10 tumor cells. Taking the findings together, we selected the derivative $\mathbf{6 b}$ for the subsequent assays due to its activity against the melanoma cell line B16-F10 (lowest $\mathrm{IC}_{50}$ ).

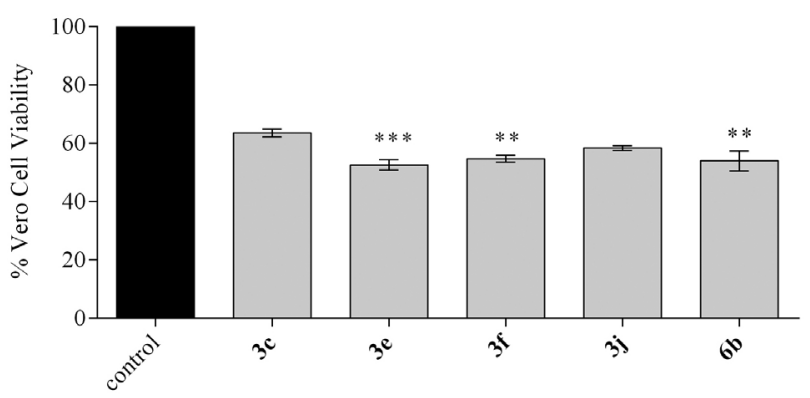

Figure 2. Effect of compounds $3 \mathbf{c}, 3 \mathbf{3 e}, \mathbf{3 f}, \mathbf{3 j}$ and $\mathbf{6 b}$ on cell viability of non-tumor cell line. Vero fibroblast-like kidney cells were treated with $100.0 \mu \mathrm{M}$ of each compound derived from cinnamic acid for $48 \mathrm{~h}$. Each bar shows the mean of percentage of survival of Vero cells determined by MTT assay. Data expressed as the mean \pm SEM. $* * p<0.01$ and $* * * p<0.001$ versus control (DMSO $0.4 \% \mathrm{v} / \mathrm{v}$ ) by one-way ANOVA and Dunn's post-hoc test.

\section{Effect of compound $\mathbf{6 b}$ on the proliferation of melanoma cells}

Cell proliferation was analyzed using the cell cycle assay. The compound $\mathbf{6 b}$ induced a shift in the deoxyribonucleic acid (DNA) content of B16-F10 cells after $48 \mathrm{~h}$ incubation (Figure 3). Specifically, the percentage of cells in the G0/G1 phase was 75.40, 78.10, and $57.90 \%$ after incubation with compound $6 \mathbf{b}$ at $12.5(p<0.05), 25.0(p<0.05)$, and $50.0 \mu \mathrm{M}$ in contrast to the $45.43 \%$ of dimethyl sulfoxide (DMSO) control cells. Further, the percentage of cells in the $\mathrm{S}$ phase corresponded to $45.9 \%$ in the dimethyl sulfoxide (DMSO) control, and 21.7 ( $p<0.0001), 14.3(p<0.0001)$, and $31.9 \%(p<0.01)$ at $12.5,25.0$, and $50.0 \mu \mathrm{M}$. For the G2/M phase, the percentages were 8.70 (DMSO control), 2.86 (at $12.5 \mu \mathrm{M} ; p<0.0001$ ), 7.64 (at $25.0 \mu \mathrm{M}$ ), and
$10.31 \%$ (at $50.0 \mu \mathrm{M} ; p<0.01$ ). Thus, these data expressed a B16-F10 cells accumulation in the G0/G1 phase and fewer cells in the S-phase (phase of duplication of genetic material), resulting in growth inhibition/cell cycle arrest. Drugs that affect the tumor cell cycle are promising, as they negatively influence the proliferation of cancer cells. ${ }^{50}$ In the case of cinnamic acid derivatives, previous studies ${ }^{47,51}$ have reported their capacity to induce cell cycle arrest in cancer cells. Therefore, our data corroborate the studies with cinnamic acid derivatives, since the compounds inhibited cell proliferation by disruption of cell cycle.

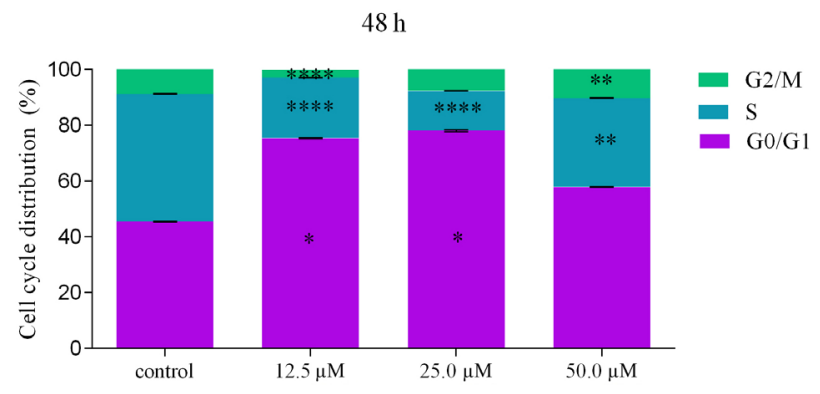

Figure 3. Effect of compound $\mathbf{6 b}$ on melanoma cell cycle. B16-F10 cells were treated with $12.5,25.0$, and $50.0 \mu \mathrm{M}$ of compound $\mathbf{6 b}$. Cells treated with DMSO $0.4 \%$ v/v were used as control. Cell cycle was evaluated using propidium iodide, followed by cytometry analysis after $48 \mathrm{~h}$ of incubation. Data expressed as the mean \pm SEM. $* p<0.05$, ${ }^{* *} p<0.01$ and $* * * * p<0.0001$ versus control (DMSO $0.4 \% \mathrm{v} / \mathrm{v}$ ) by one-way ANOVA and Dunnett's post-hoc test.

Effect of compound $\mathbf{6 b}$ on the metastatic behavior of melanoma cells

Metastasis involves a series of progressive stages which include cell migration, invasion of blood and lymph vessels, cell colonization, and the ability of these cells to survive in other organs. ${ }^{52,53}$ In order to analyze the cell migration, we evaluated the cell migration capacity through the wound healing assay using concentrations of 12.5, 25.0 and 50.0 $\mu \mathrm{M}$ of the compound $\mathbf{6 b}$ for $24 \mathrm{~h}$, all concentrations below the $\mathrm{IC}_{50}$ value. The compound $\mathbf{6 b}$ significantly reduced in approximately $42 \%$ the cell migration at the concentration of $50.0 \mu \mathrm{M}$, in relation to the DMSO control (Figure 4).

Cinnamic acid and its derivatives normally interfere with cell dynamics, decreasing cell migration. Niero and Machado-Santelli ${ }^{54}$ observed that the treatment with cinnamic acid on melanoma cells caused cytoskeleton disruption. Any change in the cell cytoskeleton interferes with cell locomotion, since these filaments are crucial for cell movement. Therefore, our data confirm the hypothesis that cinnamic acid derivatives interfere with cell migration.

Once that $\mathbf{6 b}$ interfered with cell migration and cell invasion is a key step of metastasis, invasion assay was performed. B16-F10 cells were treated with 12.5, 25.0 and 


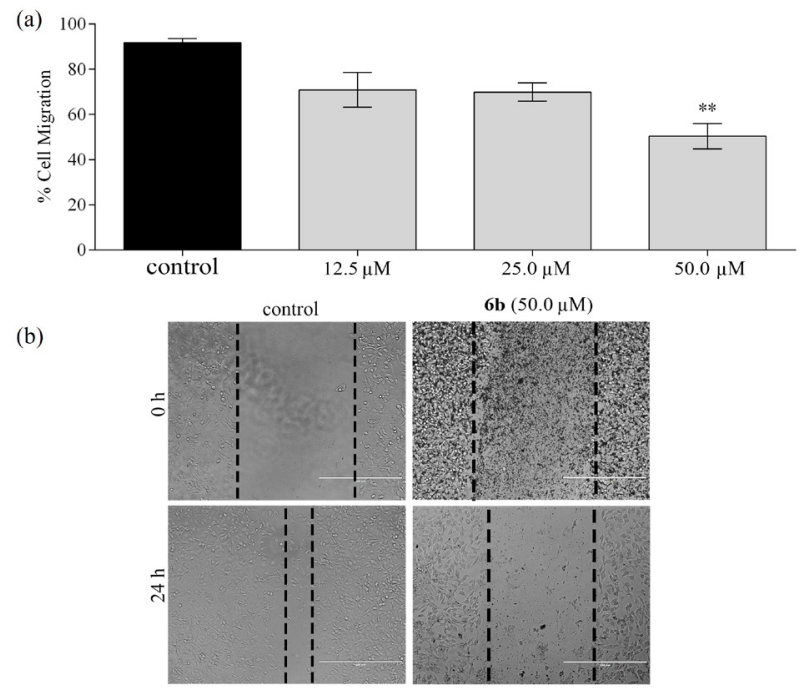

Figure 4. Effect of compound $\mathbf{6 b}$ on migration of B16-F10 melanoma cells in vitro. (a) B16-F10 metastatic melanoma was wounded with a pipette tip and then treated with $12.5,25.0$ and $50.0 \mu \mathrm{M}$ of $\mathbf{6 b}$ compound for $24 \mathrm{~h}$. (b) Photos of the wound were taken at 0 and $24 \mathrm{~h}$ after treatment with $50.0 \mu \mathrm{M}$ of the compound under $100 \times$ magnitude microscope. Data expressed as the mean \pm SEM. $* * p<0.01$ versus control $(0.04 \%$ DMSO) by one-way ANOVA and Dunnett's post-hoc test.

$50.0 \mu \mathrm{M}$ of the compound $\mathbf{6 b}$. Cell invasion decreased after $24 \mathrm{~h}$ of treatment with compound $\mathbf{6 b}$ at 12.5 (35.9\%), 25.0 (44.3\%), and 50.0 $\mu \mathrm{M}(58.7 \%)$ compared to vehicle-treated cells (DMSO 0.4\% v/v) (Figure 5).

Compounds with properties to reduce cellular invasion of cancer cells are interesting. ${ }^{55}$ The ability of these synthetic cinnamic acid derivatives to inhibit the invasive capacity of melanoma cells in vitro, shows once again that cinnamic acid and its derivatives have antiinvasive properties against cancer cells, an effect also observed against colon carcinoma cells, human lung, adenocarcinoma, and even against melanoma cells. ${ }^{28,56,57}$

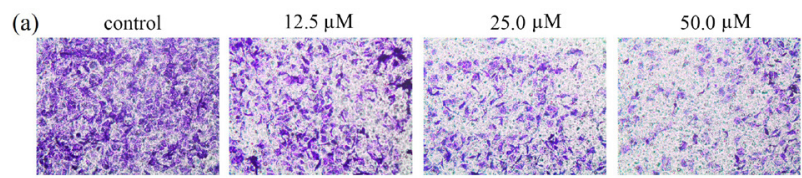

(b)

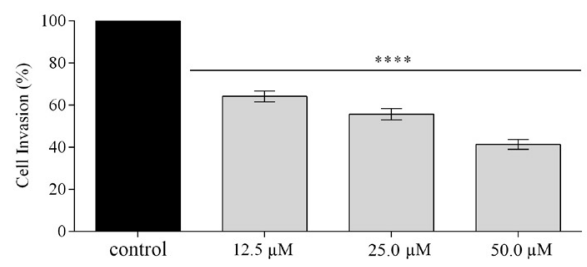

Figure 5. Effect of compound $\mathbf{6 b}$ on invasion of B16-F10 melanoma cells in vitro. (a) Photomicrography represents the cells invasion through matrigel-coated transwell. (b) The bar graph represents the percentage of invasive cell that was treated with $12.5,25.0$, and $50.0 \mu \mathrm{M}$ of compound $\mathbf{6 b}$ for $60 \mathrm{~min}$. Data expressed as the mean \pm SEM. $* * * * p<0.0001$ versus control (DMSO $0.4 \% \mathrm{v} / \mathrm{v}$ ) by one-way ANOVA and Dunnett's post-hoc test.
This anti-invasion action of compound $\mathbf{6 b}$ may be related to the activity of metalloproteinases (MMPs), since previous studies ${ }^{28,56,57}$ have shown that cinnamic acid derivatives are potent inhibitors of MMPs.

Finally, the colony formation was also assessed to evaluate the long-term effects of the compound $\mathbf{6 b}$. This compound significantly reduced colony formation, with a reduction in the number of colonies at the concentrations of $12.5(26.5 \%)$, $25.0(41.6 \%)$ and $50.0 \mu \mathrm{M}(53.3 \%)$ when compared to vehicle-treated cells (Figure 6). This important result is probably due to a set of factors, such as the negative action of compound $\mathbf{6 b}$ on cell proliferation and its impact on cell mobility and invasion, as seen in previous in vitro assays. ${ }^{58}$
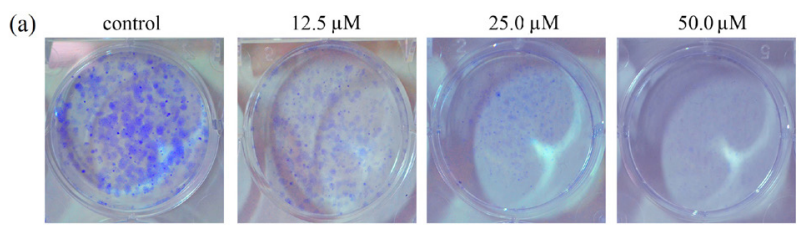

(b)

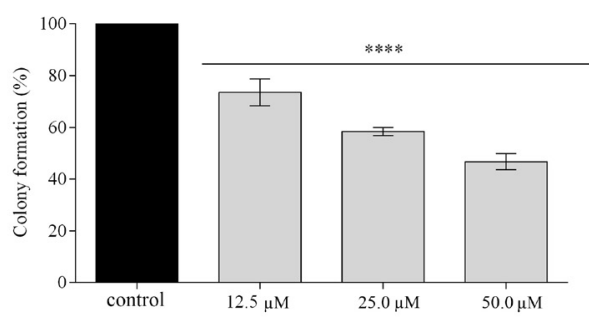

Figure 6. Effect of compound $\mathbf{6 b}$ on colony formation of B16-F10 melanoma cells in vitro. (a) Photomicrography showing the formation of B16-F10 colonies after treatment with 12.5, 25.0 and 50.0 $\mu \mathrm{M}$ of the compound $\mathbf{6 b}$. (b) The bar graph represents the percentage of colony formation after 7 days. Data expressed as mean \pm SEM. $* * * * p<0.0001$ versus control (DMSO $0.4 \% \mathrm{v} / \mathrm{v}$ ) by one-way ANOVA and Dunnett's post-hoc test.

Taken together, all the in vitro experiments performed suggested that the cinnamic acid derivative would render antiproliferative and antimetastatic effect in melanoma cells.

\section{Conclusions}

In summary, a series of novel triazole cinnamides and a hitherto unknown bis-triazole ester cinnamate were prepared and had their antiproliferative and antimetastastic activities evaluate in vitro on B16-F10 murine cell line. It was demonstrated that the derivative $\mathbf{6 b}$, the most effective compound, reduced the melanoma cell viability, generated cell cycle arrest, and influenced the metastatic behavior of melanoma cells, by decreasing migration, invasion, and colony formation. Taken together, these results clearly showed the cytotoxic, antiproliferative and antimetastatic potential of compound $\mathbf{6 b}$ against melanoma 
cells and highlight the cinnamic acid derivative as possible therapeutic target for the treatment of metastatic cancers.

\section{Experimental}

Synthesis

\section{Generalities}

The solvents were purchased from Vetec (Rio de Janeiro, RJ, Brazil), Sigma-Aldrich (St. Louis, MO, US), and Synth (Diadema, São Paulo, Brazil) and were distilled before use. Distilled water was used in the experiments. The reagents were procured from Vetec (Rio de Janeiro, RJ, Brazil), Sigma-Aldrich (St. Louis, MO, US), Synth (Diadema, São Paulo, Brazil) and Oakwood Chemical (Estill, South Carolina, US) and used without further purification. The progress of the reactions was monitored by thin layer chromatography (TLC). For the purification of the reaction products, it was employed silica gel column chromatography (SiliCycle 0.035-0.070 mm, pore diameter $6 \mathrm{~nm}$ ). The NMR spectra were recorded on Bruker (Billerica, Massachusetts, US) AVANCE DPX $200 \mathrm{MHz}$, AVANCE-III Onebay and Nanobay $400 \mathrm{MHz}$ and AVANCE-NEO $600 \mathrm{MHz}$ instruments, using $\mathrm{CDCl}_{3}, \mathrm{CD}_{3} \mathrm{OD}$, or dimethyl sulfoxide (DMSO- $d_{6}$ ) as deuterated solvents. The ${ }^{1} \mathrm{H}$ NMR data are presented as follows: chemical shift $(\delta)$ in ppm, multiplicity, number of hydrogens, $J$ values in hertz $(\mathrm{Hz})$. Multiplicities are indicated by the following abbreviations: s (singlet), brs (broad singlet), d (doublet), dd (double of doublets), $\mathrm{t}$ (triplet), $\mathrm{m}$ (multiplet), q (quartet). For fluorine-containing derivatives, the multiplicity of some carbon signals are described along with $J$ values in hertz. IR spectra were obtained using Varian 660-IR (Palo Alto, California, US) equipped with GladiATR scanning from 4000 to $500 \mathrm{~cm}^{-1}$. Melting points were determined using a MQAPF-302 melting point apparatus (Microquímica, Santa Catarina, Brazil) and are uncorrected. High resolution mass spectra (HRMS) were obtained by electron spray ionization-mass spectrometry (ESI-MS) technique on a Q-Exactive (Thermo Scientific, Waltham, Massachusetts, United States of America) mass spectrometer and Solarix (Bruker Daltonics, Bremen, Germany) mass spectrometer. Details concerning the preparation of the intermediate compounds can be found in the SI section.

Synthesis of compounds 3a-3m exemplified by the synthesis of $N$-((1-benzyl-1H-1,2,3-triazol-4-yl)methyl)cinnamamide (3a)

To a $10.0 \mathrm{~mL}$ round-bottom flask, it was added azide $(0.133 \mathrm{~g}, 1.00 \mathrm{mmol})$, water $(2.00 \mathrm{~mL})$, dichloromethane $(2.00 \mathrm{~mL})$, sodium ascorbate $(39.6 \mathrm{mg}, 0.200 \mathrm{mmol})$,
$N$-(prop-2-yn-1-yl)cinnamamide (1) (0.185 g, $1.00 \mathrm{mmol}$ ) and $\mathrm{CuSO}_{4} \cdot 5 \mathrm{H}_{2} \mathrm{O}(0.100 \mathrm{~g}, 0.400 \mathrm{mmol})$. The reaction mixture was vigorously stirred at room temperature for $30 \mathrm{~min}$. Subsequently, water $(10.0 \mathrm{~mL})$ was added and the resulting aqueous phase was extracted with dichloromethane $(3 \times 20.0 \mathrm{~mL})$. The organic extracts were combined, and the resulting organic phase was dried over anhydrous $\mathrm{Na}_{2} \mathrm{SO}_{4}$, filtered, and concentrated under reduced pressure. The compound $\mathbf{5 a}$ was purified from the residue by silica gel column chromatography eluted with hexane/ethyl acetate/methanol (5:3:1 v/v). The described procedure gave compound 5a with $58 \%$ yield $(0.185 \mathrm{~g}$, $0.580 \mathrm{mmol}$ ). White solid; mp $165.8-166.9^{\circ} \mathrm{C}$; IR (ATR) $v_{\max } / \mathrm{cm}^{-1} 3229,1614,1565,989,729 ;{ }^{1} \mathrm{H}$ NMR $(400 \mathrm{MHz}$, DMSO- $\left.d_{6}\right) \delta 4.41(\mathrm{~d}, 2 \mathrm{H}, J 3.6 \mathrm{~Hz}), 5.55(\mathrm{~s}, 2 \mathrm{H}), 6.63$ (d, $\left.1 \mathrm{H}, J_{\text {trans }} 16.0 \mathrm{~Hz}\right), 7.30-7.54(\mathrm{~m}, 11 \mathrm{~Hz}), 8.00(\mathrm{~s}, 1 \mathrm{H}), 8.57$ (brs, $1 \mathrm{H}) ;{ }^{13} \mathrm{C}$ NMR $\left(100 \mathrm{MHz}, \mathrm{DMSO}-d_{6}\right) \delta 35.0,53.4$, 122.6, 123.7, 128.2, 128.7, 128.8, 129.4, 129.6, 130.2, 135.5, 136.8, 139.7, 145.7, 165.5; HRMS (ESI ${ }^{+}$) calcd. for $\mathrm{C}_{19} \mathrm{H}_{19} \mathrm{~N}_{4} \mathrm{O}[\mathrm{M}+\mathrm{H}]^{+}: 319.1558$, found: 319.1555 .

Compounds $\mathbf{3 b} \mathbf{b} \mathbf{3} \mathbf{n}$ were prepared from the corresponding alkyne $\mathbf{2}$ and azides as described for compound $\mathbf{5 a}$. All the compounds were fully characterized by IR and NMR $\left({ }^{1} \mathrm{H}\right.$ and ${ }^{13} \mathrm{C}$ ) as well as high resolution mass spectrometry. Structures of the compounds are supported by the following data.

$N-((1-(4-($ Trifluoromethoxy)benzyl)-1H-1,2,3-triazol-4-yl)methyl) cinnamamide (3b)

White solid, obtained in 53\% yield; $\mathrm{mp} 194.0-194.8^{\circ} \mathrm{C}$; IR (ATR) $v_{\max } / \mathrm{cm}^{-1} 3247,1649,1598,1538,995 ;{ }^{1} \mathrm{H}$ NMR (400 MHz, DMSO- $\left.d_{6}\right) \delta 4.37$ (d, 2H, J $\left.5.6 \mathrm{~Hz}\right), 5.54$ (s, $2 \mathrm{H}), 5.66(\mathrm{~s}, 2 \mathrm{H}), 6.58\left(\mathrm{~d}, 1 \mathrm{H}, J_{\text {trans }} 15.6 \mathrm{~Hz}\right), 7.25-7.39$ $(\mathrm{m}, 8 \mathrm{H}), 7.45(\mathrm{~d}, 2 \mathrm{H}, J 8.0 \mathrm{~Hz}), 7.99(\mathrm{~s}, 1 \mathrm{H}), 8.53(\mathrm{t}, 1 \mathrm{H}$, $J 5.6 \mathrm{~Hz}) ;{ }^{13} \mathrm{C}$ NMR (100 MHz, DMSO- $\left.d_{6}\right) \delta 35.0,52.5$, $122.0,122.5,123.8,128.2,129.6,130.2,130.7,135.5$, $136.2,139.7,145.8,148.7,165.6$. The signal for the carbon of the $\mathrm{CF}_{3}$ group was not observed. However, the remaining spectroscopic and spectrometric data confirmed the structure of the compound. HRMS (ESI ${ }^{+}$) calcd. for $\mathrm{C}_{20} \mathrm{H}_{17} \mathrm{~F}_{3} \mathrm{~N}_{4} \mathrm{O}_{2} \mathrm{Na}[\mathrm{M}+\mathrm{Na}]^{+}:$425.1201, found: 425.1196 .

$N$-((1-(4-Methoxybenzyl)-1H-1,2,3-triazol-4-yl)methyl) cinnamamide (3c)

White solid, obtained in $41 \%$ yield; $\mathrm{mp} 162.5-163.2^{\circ} \mathrm{C}$; IR (ATR) $v_{\max } / \mathrm{cm}^{-1} 3235,1649,1609,992 ;{ }^{1} \mathrm{H}$ NMR $\left(400 \mathrm{MHz}, \mathrm{DMSO}-d_{6}\right) \delta 3.65(\mathrm{~s}, 3 \mathrm{H}), 4.35(\mathrm{~d}, 2 \mathrm{H}, J 5.6 \mathrm{~Hz})$, $5.40(\mathrm{~s}, 2 \mathrm{H}), 6.58\left(\mathrm{~d}, 1 \mathrm{H}, J_{\text {trans }} 16 \mathrm{~Hz}\right), 6.84(\mathrm{~d}, 2 \mathrm{H}, J 8.4 \mathrm{~Hz})$, 7.22 (d, 2H, J $8.4 \mathrm{~Hz}), 7.28-7.34(\mathrm{~m}, 3 \mathrm{H}), 7.38(\mathrm{~d}, 1 \mathrm{H}$, $\left.J_{\text {trans }} 16 \mathrm{~Hz}\right), 7.47(\mathrm{~d}, 2 \mathrm{H}, J 7.6 \mathrm{~Hz}), 7.89(\mathrm{~s}, 1 \mathrm{H}), 8.52(\mathrm{t}$, $1 \mathrm{H}, J 5.6 \mathrm{~Hz}$ ); ${ }^{13} \mathrm{C}$ NMR (100 MHz, DMSO- $\left.d_{6}\right) \delta 35.0,53.0$, 55.8, 114.8, 122.5, 123.4, 128.2, 128.7, 129.6, 130.2, 130.4, 
135.5, 139.7, 145.6, 159.8, 165.6; HRMS (ESI $\left.{ }^{+}\right)$calcd. for $\mathrm{C}_{20} \mathrm{H}_{21} \mathrm{~N}_{4} \mathrm{O}_{2}[\mathrm{M}+\mathrm{H}]^{+}:$349.1664, found: 349.1658 .

$N$-((1-(4-lodobenzyl)-1H-1,2,3-triazol-4-yl)methyl) cinnamamide (3d)

White solid, obtained in $69 \%$ yield; $\mathrm{mp} 208.2-209.6^{\circ} \mathrm{C}$; IR (ATR) $v_{\max } / \mathrm{cm}^{-1} 3257,1650,1606,999,750 ;{ }^{1} \mathrm{H}$ NMR $\left(400 \mathrm{MHz}, \mathrm{DMSO}-d_{6}\right) \delta 4.33(\mathrm{~d}, 2 \mathrm{H}, J 5.6 \mathrm{~Hz}), 5.43(\mathrm{~s}, 2 \mathrm{H})$, $6.55\left(\mathrm{~d}, 1 \mathrm{H}, J_{\text {trans }} 16 \mathrm{~Hz}\right), 7.02(\mathrm{~d}, 2 \mathrm{H}, J 8.0 \mathrm{~Hz}), 7.24-7.32$ $(\mathrm{m}, 3 \mathrm{H}), 7.35\left(\mathrm{~d}, 1 \mathrm{H}, J_{\text {trans }} 16 \mathrm{~Hz}\right), 7.44(\mathrm{~d}, 2 \mathrm{H}, J 6.8 \mathrm{~Hz})$, $7.63(\mathrm{~d}, 2 \mathrm{H}, J 8.0 \mathrm{~Hz}), 7.91(\mathrm{~s}, 1 \mathrm{H}), 8.50(\mathrm{t}, 1 \mathrm{H}, J 5.6 \mathrm{~Hz})$; ${ }^{13} \mathrm{C}$ NMR (100 MHz, DMSO- $\left.d_{6}\right) \delta 35.0,52.9,95.0,122.5$, $123.8,128.2,129.6,130.2,131.0,135.5,136.5,138.2$, 139.8, 145.7, 165.6; HRMS (ESI ${ }^{+}$calcd. for $\mathrm{C}_{19} \mathrm{H}_{18} \mathrm{IN}_{4} \mathrm{O}$ $[\mathrm{M}+\mathrm{H}]^{+}:$445.05254, found: 445.05201.

$N$-((1-(4-Fluorobenzyl)-1H-1,2,3-triazol-4-yl)methyl) cinnamamide (3e)

White solid, obtained in $78 \%$ yield; $\mathrm{mp} 163.8-164.5^{\circ} \mathrm{C}$; IR (ATR) $v_{\max } / \mathrm{cm}^{-1} 3232,1644,1597,1508,992 ;{ }^{1} \mathrm{H} \mathrm{NMR}$ $\left(600 \mathrm{MHz}, \mathrm{DMSO}-d_{6}\right) \delta 4.44(\mathrm{~d}, 2 \mathrm{H}, J 6.0 \mathrm{~Hz}), 5.57(\mathrm{~s}, 2 \mathrm{H})$, $6.66\left(\mathrm{~d}, 2 \mathrm{H}, J_{\text {trans }} 15.6 \mathrm{~Hz}\right), 7.20(\mathrm{t}, 2 \mathrm{H}, J 8.7 \mathrm{~Hz}), 7.35-7.42$ $(\mathrm{m}, 5 \mathrm{H}), 7.46\left(\mathrm{~d}, 1 \mathrm{H}, J_{\text {trans }} 15.6 \mathrm{~Hz}\right), 7.55(\mathrm{~d}, 2 \mathrm{H}, J 7.2 \mathrm{~Hz})$, $8.03(\mathrm{~s}, 1 \mathrm{H}), 8.60(\mathrm{t}, 1 \mathrm{H}, J 6.0 \mathrm{~Hz}) ;{ }^{13} \mathrm{C}$ NMR $(150 \mathrm{MHz}$, DMSO- $\left.d_{6}\right) \delta 34.8,52.4,116.0\left(\mathrm{~d}, J_{\mathrm{C}-\mathrm{F}} 21.0 \mathrm{~Hz}\right), 122.3$, 123.4, 128.0, 129.4, 130.0, $130.8\left(\mathrm{~d}, J_{\mathrm{C}-\mathrm{F}} 8.4 \mathrm{~Hz}\right), 132.8$ $\left(\mathrm{d}, J_{\mathrm{C}-\mathrm{F}} 3.3 \mathrm{~Hz}\right), 135.3,139.5,145.5,162.4\left(\mathrm{~d}, J_{\mathrm{C}-\mathrm{F}} 243 \mathrm{~Hz}\right)$, 165.3; HRMS (ESI ${ }^{+}$) calcd. for $\mathrm{C}_{19} \mathrm{H}_{18} \mathrm{FN}_{4} \mathrm{O}[\mathrm{M}+\mathrm{H}]^{+}$: 337.14646, found: 337.14593 .

$N$-((1-(4-Nitrobenzyl)-1H-1,2,3-triazol-4-yl)methyl) cinnamamide (3f)

Yellow solid, obtained in $66 \%$ yield; $\mathrm{mp} 184.4-186.1^{\circ} \mathrm{C}$; IR (ATR) $v_{\max } / \mathrm{cm}^{-1} 3353,1649,1610,1518,976,723$; ${ }^{1} \mathrm{H}$ NMR (400 MHz, DMSO- $\left.d_{6}\right) \delta 4.45(\mathrm{~d}, 2 \mathrm{H}, J 5.6 \mathrm{~Hz})$, $5.77(\mathrm{~s}, 2 \mathrm{H}), 6.66\left(\mathrm{~d}, 1 \mathrm{H}, J_{\text {trans }} 16 \mathrm{~Hz}\right), 7.35-7.44(\mathrm{~m}, 3 \mathrm{H})$, $7.46\left(\mathrm{~d}, 1 \mathrm{H}, J_{\text {trans }} 16 \mathrm{~Hz}\right), 7.53-7.56(\mathrm{~m}, 4 \mathrm{H}), 8.11(\mathrm{~s}, 1 \mathrm{H})$, $8.24(\mathrm{~d}, 2 \mathrm{H}, J 8.8 \mathrm{~Hz}), 8.63(\mathrm{t}, 1 \mathrm{H}, J 5.6 \mathrm{~Hz}) ;{ }^{13} \mathrm{C} \mathrm{NMR}$ $\left(100 \mathrm{MHz}, \mathrm{DMSO}-d_{6}\right) \delta 34.8,52.3,122.4,124.0,124.4$, $128.0,129.4,129.6,130.0,135.3,139.5,144.0,145.7$, 147.7, 165.6; HRMS (ESI ${ }^{+}$) calcd. for $\mathrm{C}_{19} \mathrm{H}_{18} \mathrm{~N}_{5} \mathrm{O}_{3}$ $[\mathrm{M}+\mathrm{H}]^{+}:$364.14096, found: 364.14046 .

$N$-((1-(4-Chlorobenzyl)-1H-1,2,3-triazol-4-yl)methyl) cinnamamide $(\mathbf{3 g})$

White solid, obtained in $72 \%$ yield; $\mathrm{mp} 185.6-186.8^{\circ} \mathrm{C}$; IR (ATR) $v_{\max } / \mathrm{cm}^{-1} 3260,1659,1618,972,781 ;{ }^{1} \mathrm{H} \mathrm{NMR}$ $\left(400 \mathrm{MHz}, \mathrm{DMSO}-d_{6}\right) \delta 4.44(\mathrm{~d}, 2 \mathrm{H}, J 5.5 \mathrm{~Hz}), 5.58(\mathrm{~s}$, $2 \mathrm{H}), 6.66\left(\mathrm{~d}, 1 \mathrm{H}, J_{\text {trans }} 16 \mathrm{~Hz}\right), 7.34-7.46(\mathrm{~m}, 8 \mathrm{H}), 7.56$ $(\mathrm{d}, 2 \mathrm{H}, J 7.6 \mathrm{~Hz}), 8.04(\mathrm{~s}, 1 \mathrm{H}), 8.60(\mathrm{t}, 1 \mathrm{H}, J 5.5 \mathrm{~Hz})$; ${ }^{13} \mathrm{C}$ NMR (100 MHz, DMSO- $\left.d_{6}\right) \delta 34.8,52.3,122.4,123.9$,
124.4, 128.0, 129.4, 129.6, 129,7, 135.3, 139.5, 144.0, 145.7, 147.7, 165.4; HRMS (ESI ${ }^{+}$) calcd. for $\mathrm{C}_{19} \mathrm{H}_{18} \mathrm{ClN}_{4} \mathrm{O}$ $[\mathrm{M}+\mathrm{H}]^{+}:$353.11691, found: 353.11642 .

$N$-((1-(4-Bromobenzyl)-1H-1,2,3-triazol-4-yl)methyl) cinnamamide (3h)

White solid, obtained in $81 \%$ yield; $\mathrm{mp} 196.4-197.5^{\circ} \mathrm{C}$; IR (ATR) $v_{\max } / \mathrm{cm}^{-1} 3253,1657,1614,1566,971,752$; ${ }^{1} \mathrm{H}$ NMR (400 MHz, DMSO- $\left.d_{6}\right) \delta 4.44(\mathrm{~d}, 2 \mathrm{H}, J 5.6 \mathrm{~Hz})$, $5.57(\mathrm{~s}, 2 \mathrm{H}), 6.66\left(\mathrm{~d}, 1 \mathrm{H}, J_{\text {trans }} 16.0 \mathrm{~Hz}\right), 7.29(\mathrm{~d}, 2 \mathrm{H}$, $J 8.4 \mathrm{~Hz}), 7.37-7.44(\mathrm{~m}, 3 \mathrm{H}), 7.46\left(\mathrm{~d}, 1 \mathrm{H}, J_{\text {trans }} 16 \mathrm{~Hz}\right)$, 7.54-7.59 (m, 4H), $8.04(\mathrm{~s}, 1 \mathrm{H}), 8.60(\mathrm{t}, 1 \mathrm{H}, J 5.6 \mathrm{~Hz})$; ${ }^{13} \mathrm{C}$ NMR (100 MHz, DMSO- $\left.d_{6}\right) \delta 34.8,52.5,121.9$, $122.4,123.6,128.0,129.4,130.0,130.7,132.1,135.3$, 136.0, 139.5, 145.5, 165.3; HRMS (ESI ${ }^{+}$) calcd. for $\mathrm{C}_{19} \mathrm{H}_{17} \mathrm{BrN}_{4} \mathrm{ONa}[\mathrm{M}+\mathrm{Na}]^{+}: 419.04834$, found: 419.04788 .

$N$-((1-(4-Methylbenzyl)-1H-1,2,3-triazol-4-yl)methyl) cinnamamide (3i)

White solid, obtained in $78 \%$ yield; $\mathrm{mp} 182.8-183.8^{\circ} \mathrm{C}$; IR (ATR) $v_{\max } / \mathrm{cm}^{-1} 3268,1652,1609,1539,988,757$; ${ }^{1} \mathrm{H}$ NMR (400 MHz, DMSO- $d_{6}$ ) $\delta 2.28$ (s, 3H), 4.43 (d, $2 \mathrm{H}, J 5.6 \mathrm{~Hz}), 5.51(\mathrm{~s}, 2 \mathrm{H}), 6.66\left(\mathrm{~d}, 1 \mathrm{H}, J_{\text {trans }} 16 \mathrm{~Hz}\right), 7.17$ $(\mathrm{d}, 2 \mathrm{H}, J 8 \mathrm{~Hz}), 7.23(\mathrm{~d}, 2 \mathrm{H}, J 8 \mathrm{~Hz}), 7.16-7.24(\mathrm{~m}, 4 \mathrm{H})$, 7.36-7.41 (m, 3H), $7.46\left(\mathrm{~d}, 1 \mathrm{H}, J_{\text {trans }} 16 \mathrm{~Hz}\right), 7.55(\mathrm{~d}, 2 \mathrm{H}$, $J 6.4 \mathrm{~Hz}), 7.94(\mathrm{~s}, 1 \mathrm{H}), 8.58(\mathrm{t}, 1 \mathrm{H}, J 5.6 \mathrm{~Hz}) ;{ }^{13} \mathrm{C} \mathrm{NMR}$ $\left(150 \mathrm{MHz}, \mathrm{DMSO}-d_{6}\right) \delta 20.7,34.4,52.6,121.9,122.9$, 127.6, 128.1, 129.0, 129.3, 129.5, 133.1, 134.9, 137.5, 139.1, 145.0, 164.9; HRMS (ESI ${ }^{+}$) calcd. for $\mathrm{C}_{20} \mathrm{H}_{21} \mathrm{~N}_{4} \mathrm{O}$ $[\mathrm{M}+\mathrm{H}]^{+}:$333.17154, found: 333.17104 .

$N$-((1-(4-(Trifluoromethyl)benzyl)-1H-1,2,3-triazol-4-yl) methyl)cinnamamide (3j)

White solid, obtained in $71 \%$ yield; $\mathrm{mp} 214.1-215.3^{\circ} \mathrm{C}$; IR (ATR) $v_{\max } / \mathrm{cm}^{-1} 3253,1649,1602,1112 ;{ }^{1} \mathrm{H}$ NMR $\left(400 \mathrm{MHz}, \mathrm{DMSO}-d_{6}\right) \delta 4.45(\mathrm{~d}, 2 \mathrm{H}, J 5.4 \mathrm{~Hz}), 5.71(\mathrm{~s}$, $2 \mathrm{H}), 6.67\left(\mathrm{~d}, 1 \mathrm{H}, J_{\text {trans }} 16 \mathrm{~Hz}\right), 7.35-7.43(\mathrm{~m}, 3 \mathrm{H}), 7.47(\mathrm{~d}$, $\left.1 \mathrm{H}, J_{\text {trans }} 16 \mathrm{~Hz}\right), 7.51-7.56(\mathrm{~m}, 4 \mathrm{H}), 7.75(\mathrm{~d}, 2 \mathrm{H}, J 8.4 \mathrm{~Hz})$, $8.10(\mathrm{~s}, 1 \mathrm{H}), 8.62(\mathrm{t}, 1 \mathrm{H}, J 5.4 \mathrm{~Hz}) ;{ }^{13} \mathrm{C}$ NMR $(100 \mathrm{MHz}$, DMSO- $\left.d_{6}\right) \delta 34.8,52.5,122.4,123.8,126.1(\mathrm{q}, J 3.7 \mathrm{~Hz})$, 128.0, 129.2, 129.4, 129.9, 135.3, 139.5, 141.2, 145.6, 165.4; HRMS (ESI ${ }^{+}$) calcd. for $\mathrm{C}_{20} \mathrm{H}_{18} \mathrm{~F}_{3} \mathrm{~N}_{4} \mathrm{O}[\mathrm{M}+\mathrm{H}]^{+}: 387.14327$, found: 387.14283 .

$N$-((1-(4-Isopropylbenzyl)-1H-1,2,3-triazol-4-yl)methyl) cinnamamide (3k)

White solid, obtained in $72 \%$ yield; $\mathrm{mp} 199.1-200.5^{\circ} \mathrm{C}$; IR (ATR) $v_{\max } / \mathrm{cm}^{-1} 3279,1653,1610,992 ;{ }^{1} \mathrm{H}$ NMR $\left(400 \mathrm{MHz}, \mathrm{DMSO}-d_{6}\right) \delta 1.17(\mathrm{~d}, 6 \mathrm{H}, J 6.9 \mathrm{~Hz}$ ), 2.86 (septet, $1 \mathrm{H}, J 6.9 \mathrm{~Hz}), 4.42(\mathrm{~d}, 2 \mathrm{H}, J 5.3 \mathrm{~Hz}), 5.52(\mathrm{~s}, 2 \mathrm{H}), 6.65(\mathrm{~d}$, $\left.1 \mathrm{H}, J_{\text {trans }} 16 \mathrm{~Hz}\right), 7.22-7.28(\mathrm{~m}, 4 \mathrm{H}), 7.35-7.43(\mathrm{~m}, 3 \mathrm{H}), 7.45$ 
$\left(\mathrm{d}, 1 \mathrm{H}, J_{\text {trans }} 16 \mathrm{~Hz}\right), 7.55(\mathrm{~d}, 2 \mathrm{H}, J 7.3 \mathrm{~Hz}), 8.01(\mathrm{~s}, 1 \mathrm{H})$, $8.59(\mathrm{t}, 1 \mathrm{H}, J 5.3 \mathrm{~Hz}) ;{ }^{13} \mathrm{C}$ NMR (100 MHz, DMSO- $\left.d_{6}\right)$ $\delta$ 24.2, 33.6, 34.8, 53.0, 122.4, 123.4, 127.1, 128.0, 128.6, 129.4, 130.0, 134.0, 135.3, 139.5, 145.4, 148.9, 165.3; HRMS $\left(\mathrm{ESI}^{+}\right)$calcd. for $\mathrm{C}_{22} \mathrm{H}_{25} \mathrm{~N}_{4} \mathrm{O}[\mathrm{M}+\mathrm{H}]^{+}:$361.20284, found: 361.20230 .

$N$-((1-(3,4-Difluorobenzyl)-1H-1,2,3-triazol-4-yl)methyl) cinnamamide (3I)

White solid, obtained in $77 \%$ yield; $\mathrm{mp} 149.3-150.8^{\circ} \mathrm{C}$; IR (ATR) $v_{\max } / \mathrm{cm}^{-1} 3241,1518 ;{ }^{1} \mathrm{H}$ NMR (400 MHz, DMSO- $\left.d_{6}\right) \delta 4.43(\mathrm{~d}, 2 \mathrm{H}, J 5.5 \mathrm{~Hz}), 5.57(\mathrm{~s}, 2 \mathrm{H}), 6.65(\mathrm{~d}$, $\left.1 \mathrm{H}, J_{\text {trans }} 16 \mathrm{~Hz}\right), 7.20(\mathrm{~s}, 1 \mathrm{H}), 7.35-7.47(\mathrm{~m}, 6 \mathrm{H}), 7.55(\mathrm{~d}$, $2 \mathrm{H}, J 6.9 \mathrm{~Hz}), 8.06(\mathrm{~s}, 1 \mathrm{H}), 8.59(\mathrm{t}, 1 \mathrm{H}, J 5.5 \mathrm{~Hz}) ;{ }^{13} \mathrm{C} \mathrm{NMR}$ $\left(100 \mathrm{MHz}, \mathrm{DMSO}-d_{6}\right) \delta 34.3,51.5,117.3(\mathrm{~d}, J 17.4 \mathrm{~Hz})$, 117.8 (d, $J 17.4 \mathrm{~Hz}), 121.8,123.0,125.1-125.2(\mathrm{~m}), 127.4$, $128.9,129.4,133.6-133.7$ (m), 134.7, 139.0, 145.0, 147.9148.0 (m), 150.3-150.5 (m), 164.8; HRMS (ESI ${ }^{+}$) calcd. for $\mathrm{C}_{19} \mathrm{H}_{17} \mathrm{~F}_{2} \mathrm{~N}_{4} \mathrm{O}[\mathrm{M}+\mathrm{H}]^{+}:$355.13704, found: 355.13663 .

$N$ - ( ( 1 - ( 7-Hydroxy - 2 - oxo- $2 \mathrm{H}$ - ch rome n - 3 - yl ) $1 \mathrm{H}-1,2,3$-triazol-4-yl)methyl)cinnamamide (3m)

White solid, obtained in $30 \%$ yield; $\mathrm{mp} 224.4-224.9^{\circ} \mathrm{C}$; IR (ATR) $v_{\max } / \mathrm{cm}^{-1} 3250,3065,1728,1600 ;{ }^{1} \mathrm{H}$ NMR (400 MHz, DMSO- $d_{6}$ ) $\delta 4.54(\mathrm{~d}, 2 \mathrm{H}, J 5.2 \mathrm{~Hz}), 6.69$ (d, $\left.1 \mathrm{H}, J_{\text {trans }} 15.6 \mathrm{~Hz}\right), 6.85-6.92(\mathrm{~s}, 2 \mathrm{H}, \mathrm{m}), 7.36-7.44(\mathrm{~m}, 3 \mathrm{H})$, $7.49\left(\mathrm{~d}, 1 \mathrm{H}, J_{\text {trans }} 15.6 \mathrm{~Hz}\right), 7.56(\mathrm{~d}, 2 \mathrm{H}, J 6.9 \mathrm{~Hz}), 7.75$ $(\mathrm{d}, 1 \mathrm{H}, J 8.5 \mathrm{~Hz}), 8.44(\mathrm{~s}, 1 \mathrm{H}), 8.58(\mathrm{~s}, 1 \mathrm{H}), 8.73(\mathrm{t}, 1 \mathrm{H}$, $J 5.2 \mathrm{~Hz}) ;{ }^{13} \mathrm{C}$ NMR (100 MHz, DMSO- $\left.d_{6}\right) \delta 34.7,102.6$, $110.8,114.8,119.8,122.3,124.3,128.0,129.4,130.0$, $131.4,135.3,136.6,139.6,145.5,155.1,156.8,163.0$, 165.5; HRMS (ESI ${ }^{+}$) calcd. for $\mathrm{C}_{19} \mathrm{H}_{16} \mathrm{~F}_{2} \mathrm{~N}_{4} \mathrm{ONa}[\mathrm{M}+\mathrm{Na}]^{+}$: 411.10693, found: 411.10663 .

$N$-((1-(7-(Diethylamino)-2-oxo-2H-chromen-3-yl)$1 \mathrm{H}$-1,2,3-triazol-4-yl)methyl)cinnamamide (3n)

Yellow solid, obtained in $63 \%$ yield; $\mathrm{mp} 206.5-207.4^{\circ} \mathrm{C}$; IR (ATR) $v_{\max } / \mathrm{cm}^{-1} 3332,1731,1613,968 ;{ }^{1} \mathrm{H} \mathrm{NMR}$ (400 MHz, DMSO- $d_{6}$ ) $\delta$ 1.13-1.47 (m, 6H), 3.46-3.51 (m, $4 \mathrm{H}), 4.53(\mathrm{~s}, 2 \mathrm{H}), 6.66-6.71(\mathrm{~m}, 2 \mathrm{H}), 6.82(\mathrm{~d}, 1 \mathrm{H}, J 9.6 \mathrm{~Hz})$, 7.40-7.42 (m, 3H), $7.48\left(\mathrm{~d}, 1 \mathrm{H}, J_{\text {trans }} 16 \mathrm{~Hz}\right), 7.56-7.64(\mathrm{~m}$, $3 \mathrm{H}), 8.40(\mathrm{~s}, 1 \mathrm{H}), 8.45(\mathrm{~s}, 1 \mathrm{H}), 8.71(\mathrm{~s}, 1 \mathrm{H}) ;{ }^{13} \mathrm{C} \mathrm{NMR}$ $\left(100 \mathrm{MHz}, \mathrm{DMSO}-d_{6}\right) \delta 12.5,34.4,44.4,96.6,106.7,110.2$, 116.5, 122.0, 123.9, 127.7, 129.1, 129.7, 130.7, 135.0, 136.7, 139.3, 145.0, 151.6, 155.8, 156.9, 165.1; HRMS (ESI ${ }^{+}$) calcd. for $\mathrm{C}_{25} \mathrm{H}_{26} \mathrm{~N}_{5} \mathrm{O}_{3}[\mathrm{M}+\mathrm{H}]^{+}$: 444.20356, found: 444.20352.

Synthesis of $\left(2 E, 2^{\prime} E\right)-N, N^{\prime}-(((($ oxybis(ethane-2,1-diyl $))$ bis(oxy))bis(ethane-2,1-diyl))bis(1H-1,2,3-triazole-1,4-diyl)) bis(methylene))bis(3-phenylacrylamide) (6a)

This compound was prepared via the reaction between azide $\mathbf{4}$ and compound $\mathbf{2}$, using the same methodology described for compound 3a, however, $2.00 \mathrm{mmol}$ of compound 2 was used for $1.00 \mathrm{mmol}$ of azide 4 . A white solid was obtained in $34 \%$ yield, mp 152.4-153.5 ${ }^{\circ} \mathrm{C}$; IR (ATR) $v_{\max } / \mathrm{cm}^{-1} 3266,1667,1629,971 ;{ }^{1} \mathrm{H} \mathrm{NMR}$ (400 MHz, CD $\mathrm{CD}_{3} \delta 3.48-3.53(\mathrm{~m}, 8 \mathrm{H}), 3.82(\mathrm{t}, 4 \mathrm{H}$, $J 5.2 \mathrm{~Hz}), 4.52(\mathrm{t}, 4 \mathrm{H}, J 5.2 \mathrm{~Hz}), 4.55(\mathrm{~s}, 4 \mathrm{H}), 6.62(\mathrm{~d}, 2 \mathrm{H}$, $\left.J_{\text {trans }} 16 \mathrm{~Hz}\right), 7.35-7.39(\mathrm{~m}, 6 \mathrm{H}), 7.52-7.58(\mathrm{~m}, 6 \mathrm{H}), 7.92$ $(\mathrm{s}, 2 \mathrm{H}) ;{ }^{13} \mathrm{C}$ NMR $\left(100 \mathrm{MHz}, \mathrm{CD}_{3} \mathrm{OD}\right) \delta 35.8,51.4,70.3$, 71.5, 121.6, 125.1, 128.9, 130.0, 130.9, 136.2, 142.2, 146.0, 168.4; HRMS (ESI ${ }^{+}$calcd. for $\mathrm{C}_{32} \mathrm{H}_{38} \mathrm{~N}_{8} \mathrm{O}_{5} \mathrm{Na}[\mathrm{M}+\mathrm{Na}]^{+}$: 637.28629, found: 637.28741 .

((((Oxybis(ethane-2,1-diyl))bis(oxy))bis(ethane-2,1-diyl)) bis(1H-1,2,3-triazole-1,4-diyl))bis(methylene) (2E,2' $E)$-bis (3-phenylacrylate) (6b)

This compound was obtained in $23 \%$ as colorless oil from the reaction of azide $\mathbf{4}$ and ester $\mathbf{5}$, using the same methodology described for compound $\mathbf{6 a}$, IR (ATR) $v_{\max } / \mathrm{cm}^{-1} 3136,1713,1636,1160 ;{ }^{1} \mathrm{H}$ NMR (400 MHz, $\left.\mathrm{CDCl}_{3}\right) \delta 3.53-3.60(\mathrm{~m}, 8 \mathrm{H}), 3.86(\mathrm{t}, 4 \mathrm{H}, J 5.1 \mathrm{~Hz}), 4.54$ $(\mathrm{t}, 4 \mathrm{H}, J 5.1 \mathrm{~Hz}), 5.36(\mathrm{~s}, 4 \mathrm{H}), 6.43\left(\mathrm{~d}, 2 \mathrm{H}, J_{\text {trans }} 16.0 \mathrm{~Hz}\right)$, 7.36-7.39 (m, 6H), 7.48-7.51 (m, 4H), $7.70(\mathrm{~d}, 2 \mathrm{H}$, $\left.J_{\text {trans }} 16 \mathrm{~Hz}\right), 7.85(\mathrm{~s}, 2 \mathrm{H}) ;{ }^{13} \mathrm{C} \mathrm{NMR}\left(100 \mathrm{MHz}, \mathrm{CDCl}_{3}\right)$ $\delta$ 50.4, 57.5, 69.3, 70.46, 70.54, 117.5, 125.11, 128.1, 128.9, 130.5, 134.2, 142.6, 145.6, 166.7; HRMS (ESI ${ }^{+}$) calcd. for $\mathrm{C}_{32} \mathrm{H}_{37} \mathrm{~N}_{6} \mathrm{O}_{7}[\mathrm{M}+\mathrm{H}]^{+}:$617.27237, found: 617.27271.

\section{Cell culture}

Murine melanoma cells (B16-F10) were kindly provided by Dr Mirian T. Paes Lopes (Department of Pharmacology, Universidade Federal de Minas Gerais, Belo Horizonte, Minas Gerais, Brazil). African green monkey kidney cell line (Vero) was kindly provided by Dr Juliana Lopes Rangel Fietto (Department of Biochemistry and Molecular Biology, Universidade Federal de Viçosa, Viçosa, Minas Gerais, Brazil). The cells were grown in Roswell Park Memorial Institute (RPMI-1640 medium Sigma-Aldrich, St. Louis, MO, US) supplemented with $10 \%(\mathrm{v} / \mathrm{v})$ of fetal bovine serum (FBS) (LGC Biotecnologia, Cotia, Brazil), $100 \mathrm{~g} \mathrm{~mL}^{-1}$ streptomycin, and 100 units $\mathrm{mL}^{-1}$ penicillin at $\mathrm{pH} 7.2$ and $37{ }^{\circ} \mathrm{C}$ under $5 \% \mathrm{CO}_{2}$ atmosphere.

Cell viability assay and cytotoxicity

B16-F10 cells were plated in 96-well at a concentration of $1.0 \times 10^{4}$ cells per well in a 96-well flat bottom microplate. The cells grew for $24 \mathrm{~h}$ and were treated with the concentration of $100 \mu \mathrm{M}$ of each synthesized 
compound derived from cinnamic acid 3a-3n, 6a and 6b. DMSO $(0.4 \% \mathrm{v} / \mathrm{v})$ and RPMI-1640 were used as control. After $48 \mathrm{~h}$ of treatment, the cell viability was determined by MTT (3-(4,5 dimethylthiazol-2-yl)-2,5 diphenyltetrazolium bromide) (Sigma-Aldrich, St. Louis, MO, US) metabolization. The MTT solution was added to each well (final concentration $5 \mathrm{mg} \mathrm{mL}^{-1}$ ) and the plate was incubated for $3 \mathrm{~h}$. Finally, $100 \mu \mathrm{L}$ of DMSO were added to each well and the absorbance was measured in a plate reader (Sinergy HT, Biotek) at $540 \mathrm{~nm}$. Results were normalized considering the cultures treated with $0.4 \%$ DMSO (control). The half-maximal inhibitory concentration $\left(\mathrm{IC}_{50}\right)$ of the most active compounds was also analyzed using the MTT method, after treating the B16-F10 cells with increasing doses $(0-200.0 \mu \mathrm{M})$ of these compounds. The $\mathrm{IC}_{50}$ was calculated as previously reported. ${ }^{59}$

\section{Cell viability on non-tumor cell line}

Vero cells, a non-tumor cell line, were plated at a concentration of $8.0 \times 10^{4}$ cells per well in a 96-well flat bottom microplate. The cells grew for $24 \mathrm{~h}$ and were treated with the concentration of $100.0 \mu \mathrm{M}$ of the five best compounds selected after the cell viability test in B16-F10. DMSO (0.4\% v/v) and RPMI-1640 were used as control. After $48 \mathrm{~h}$ of treatment, the cell viability was determined by MTT Sigma-Aldrich (St. Louis, MO, US) metabolization. The MTT solution was added to each well (final concentration $5 \mathrm{mg} \mathrm{mL}^{-1}$ ) and the plate was incubated for $3 \mathrm{~h}$. Finally, $100 \mu \mathrm{L}$ of DMSO was added to each well and the absorbance was measured in a plate reader (Sinergy HT, Biotek, Winooski, Vermont, USA) at $540 \mathrm{~nm}$. Results were normalized considering the cultures treated with DMSO 0.4\% v/v (control).

\section{Cell cycle assay}

B16-F10 cells were seeded on a 6-well plate at a density of $2.5 \times 10^{5}$ cells per well and treated with compound $\mathbf{6 b}$ at the concentrations of $12.5,25.0$, and $50.0 \mu \mathrm{M}$ for $48 \mathrm{~h}$. DMSO $(0.4 \% \mathrm{v} / \mathrm{v})$ was used as vehicle control. Then the cells were fixed in $70 \%$ ethanol, washed in phosphatebuffered saline (PBS), and incubated for $60 \mathrm{~min}$ in PBS containing propidium iodide $\left(50 \mu \mathrm{g} \mathrm{mL}^{-1}\right.$, Sigma-Aldrich, St. Louis, MO, US) and RNase A (0.2 $\mathrm{mg} \mathrm{mL}^{-1}$, Invitrogen). The samples were analyzed by flow cytometry (FACS Verse, BD Bioscience, Franklanes, New Jersey, USA).

\section{Cell migration assay}

The wound-healing assay was conducted to evaluate the ability of the compound $\mathbf{6 b}$ to inhibit cell migration. B16-F10 cells were seeded onto 24-well plate at a concentration of $1.0 \times 10^{5}$ cells per well and allowed to reach full confluence after incubation overnight at $37^{\circ} \mathrm{C}$ under $5 \% \mathrm{CO}_{2}$ atmosphere. Monolayers were then wounded using a sterile $200 \mu \mathrm{L}$ pipette tip. Cells were washed twice with PBS to remove detached cells and then treated with the compounds at the concentrations of 12.5, 25.0 and 50.0 $\mu \mathrm{M}$. The DMSO vehicle treatment $(0.4 \% \mathrm{v} / \mathrm{v})$ was used as control. Photos of the wound were taken using an inverted microscope (Life Technologies, Carlsbad, California, USA). Wound closure rates were then calculated quantitatively as the difference between wound width at 0 and $24 \mathrm{~h}$. Results were expressed as a percentage of cell migration.

\section{Cell invasion assay}

The matrigel matrix (BD Biosciences, Franklin Lakes, New Jersey, US) was diluted with serum-free RPMI-1640 culture medium at 1:12 ratio. Subsequently, the upper chamber of the transwell $(8.0 \mu \mathrm{m}$ polycarbonate membrane, Corning) was coated with $35 \mu \mathrm{L}$ diluted Matrigel matrix and incubated at $37^{\circ} \mathrm{C}$, for $2 \mathrm{~h}$, for full condensation. Then, the B16-F10 cells were re-suspended with serum-free RPMI1640 , treated with $\mathbf{6 b}$ at $12.5,25.0$, and $50.0 \mu \mathrm{M}$ for $60 \mathrm{~min}$, and inoculated into the upper chamber Matrigel-precoated $\left(5.0 \times 10^{4}\right.$ cells, $100 \mu \mathrm{L}$ per well). The DMSO-vehicle treatment $(0.4 \% \mathrm{v} / \mathrm{v})$ was used as control. The well was filled with $650 \mu \mathrm{L}$ of culture medium containing $10 \% \mathrm{v} / \mathrm{v}$ FBS as a chemoattractant. After $24 \mathrm{~h}$, the chambers were fixed in methanol for $30 \mathrm{~min}$, washed and stained with toluidine blue (1\% v/v, Sigma-Aldrich, St. Louis, MO, US) for $15 \mathrm{~min}$. Images from 10 fields were chosen at random/group, captured using an inverted microscope (Leica Microsystems, Wetzlar, Germany) and the cells were counted using the ImageJ software. ${ }^{60}$ The results were expressed as a percentage of cell invasion.

\section{Cell colony assay}

B16-F10 cells were seeded in 6-well plates in triplicate at the density of $1.0 \times 10^{3}$ cells per well. After $24 \mathrm{~h}$, the cells were treated with the compound $\mathbf{6 b}$ at 12.5, 25.0, and $50.0 \mu \mathrm{M}$ for $24 \mathrm{~h}$. The complete medium was exchanged for complete medium with $2 \% \mathrm{FBS}$, and the cells were cultured for 7 days. The colonies formed were then fixed and stained with toluidine blue solution (1\% v/v, SigmaAldrich, St. Louis, MO, US) and methanol (20\% v/v). Colonies were counted by using ImageJ software and the results were expressed as a percentage of the untreated control cultures. ${ }^{60}$ 


\section{Statistical analysis}

All numeric data were obtained from three independent experiments, each experiment with triplicate, and are shown as mean \pm standard error of the mean (SEM). The analyses were performed using Microsoft Excel (Microsoft Office Software System) and GraphPad Prism (GraphPad Software Inc.). ${ }^{61,62}$ The statistical analyses were carried out by oneway analysis of variance (ANOVA) followed by Dunn's or Dunnett's tests. ${ }^{*} p<0.05, * * p<0.01, * * * p<0.001$ and $* * * * p<0001$ were considered significant.

\section{Supplementary Information}

Supplementary data are available free of charge at http://jbcs.sbq.org.br as PDF file.

\section{Acknowledgments}

We are grateful to FAPEMIG, CNPq, and CAPES for financial support.

\section{Author Contributions}

FSS was responsible for investigation, data curation, writing original draft and writing-review and editing; JAV was responsible for investigation, data curation and writing original draft; LSS performed acquisition of data; TBG performed acquisition of data; GDAL was responsible for biological experiments; LLO was responsible for data curation and formal analysis; MMN conducted the biological experiments; RRT was responsible for conceptualization, formal analysis, funding acquisition, writing original draft and supervision; RPF was responsible for planning, project administration, funding acquisition, writing-review and coordination.

\section{References}

1. Bishop, J. A. N.; Jewell, R. In Principles and Practice of Medical Genetics, $6^{\text {th }}$ ed.; Rimoin, D.; Pyeritz, R.; Korf, B., eds; Academic Press: Cambridge, UK, 2013.

2. D’Orazio, J. A.; Jarrett, S.; Marsch, A.; Lagrew, J.; Clear, L.; In Melanoma - Epidemiology, Genetics and Risk Factors; Davids, L., ed.; IntechOpen: London, UK, 2013.

3. Bandarchi, B.; Ma, L.; Navab, R.; Seth, A.; Rasty, G.; Dermatol. Res. Pract. 2010, 2010, ID 583748.

4. Cichorek, M.; Wachulska, M.; Stasiewicz, A.; Tyminska, A.; Adv. Dermatol. Allergol. 2013, 30, 30.

5. Cancer Facts \& Figures 2020. Available at https://www.cancer. org/research/cancer-facts-statistics/all-cancer-facts-figures/ cancer-facts-figures-2020.html, accessed in July 2021.

6. Apalla, Z.; Lallas, A.; Sotiriou, E.; Lazaridou, E.; Ioannides, D.; Dermatol. Pract. Concept. 2017, 7, 1.

7. Siegel, R. L.; Miller, K. D.; Jemal, A.; Ca-Cancer J. Clin. 2020, 70,7 .

8. de Oliveira Santos, M.; Rev. Bras. Cancerol. 2020, 66, 1.

9. Landi, M. T.; Bishop, D. T.; MacGregor, S.; Machiela, M. J.; Stratigos, A. J.; Ghiorzo, P.; Brossard, M.; Calista, D.; Choi, J.; Fargnoli, M. C.; Zhang, T.; Rodolfo, M.; Trower, A. J.; Menin, C.; Martinez, J.; Hadjisavvas, A.; Song, L.; Stefanaki, I.; Scolyer, R.; Yang, R.; Goldstein, A. M.; Potrony, M.; Kypreou, K. P.; Pastorino, L.; Queirolo, P.; Pellegrini, C.; Cattaneo, L.; Zawistowski, M.; Gimenez-Xavier, P.; Rodriguez, A.; Elefanti, L.; Manoukian, S.; Rivoltini, L.; Smith, B. H.; Loizidou, M. A.; Regno, L. D.; Massi, D.; Mandala, M.; Khosrotehrani, K.; Akslen, L. A.; Amos, L. A.; Andresen, P. A.; Avril, M.-F.; Azizi, M.-F.; Soyer, H. P.; Bataille, V.; Dalmasso, B.; Bowdler, L. M.; Burdon, K. P.; Chen, W. V.; Codd, V.; Craig, J. E.; Dębniak, T.; Falchi, M.; Fang, S.; Friedman, E.; Simi, S.; Galan, P.; Garcia-Casado, Z.; Gillanders, E. M.; Gordon, S.; Green, A.; Gruis, N. A.; Hansson, J.; Harland, M.; Harris, J.; Helsing, P.; Henders, A.; Marko Hočevar, V.; Höiom, D.; Hunter, C.; Ingvar, R.; Kumar, J.; Lang, Lathrop, G. M.; Lee, J. E.; Li, X.; Lubiński, J.; Mackie, R. M.; Malt, M.; Malvehy, J.; McAloney, H.; Mohamdi, K.; Molven, A.; Moses, E. K.; Neale, R. E.; Novaković, S.; Nyholt, D. R.; Olsson, H.; Orr, N.; Fritsche, L. G.; Puig-Butille, J. A.; Qureshi, A. A.; Radford-Smith, G. L.; Randerson-Moor, J.; Requena, C.; Rowe, C.; Samani, N. J.; Sanna, M.; Schadendorf, D.; Schulze, H.-J.; Simms, L. A.; Smithers, M.; Song, F.; Swerdlow, A. J.; van der Stoep, N.; Kukutsch, N. A.; Visconti, A.; Wallace, L.; Ward, S. V.; Wheeler, L.; Sturm, R. A.; Hutchinson, A.; Jones, K.; Malasky, M.; Vogt, A.; Zhou, W.; Pooley, K. A.; Elder, D. E.; Han, J.; Hicks, B.; Hayward, N. K.; Kanetsky, P. A.; Brummett, C.; Montgomery, G. W.; Olsen, C. M.; Hayward, C.; Dunning, A. M.; Martin, N. G.; Evangelou, E.; Mann, G. J.; Long, G.; Pharoah, P. D. P.; Easton, D. F.; Barrett, J. H.; Cust, A. E.; Abecasis, G.; Duffy, D. L.; Whiteman, D. C.; Gogas, H.; de Nicolo, A.; Tucker, M. A.; Newton-Bishop, M. A.; Nat. Genet. 2020, 52, 494.

10. Maio, M. M.; Grob, J.-J.; Aamdal, S.; Bondarenko, I.; Robert, C.; Thomas, L.; Garbe, C. V. C.-S.; Testori, A.; Chen, T.-T.; Tschaika, M.; Walchok, J. D.; J. Clin. Oncol. 2015, 33, 1191.

11. Mattia, G.; Puglisi, R.; Ascione, B.; Malorni, W.; Carè, A.; Matarrese, P.; Cell Death Discovery 2018, 25, 112.

12. Bhatia, S.; Tykodi, S. S.; Thompson, J. A.; Oncology 2009, 23, 488.

13. Balch, C. M.; Buzaid, A. C.; Soong, S.-J.; Atkins, M. B.; Cascinelli, N.; Coit, D. G.; Fleming, I. D.; Gershenwald, J. E.; Houghton Jr., A.; Kirkwood, J. M.; McMasters, K. M.; Mihm, M. F.; Morton, D. L.; Reintgen, D. S.; Ross, M. I.; Sober, A.; Thompson, J. A.; Thompson, J. F.; J. Clin. Oncol. 2009, 19, 3635. 
14. Atallah, E.; Flaherty, L.; Curr. Treat. Options Oncol. 2005, 6, 185 .

15. Domingues, B.; Lopes, J. M.; Soares, P.; Pópulo, H.; ImmunoTargets Ther. 2018, 7, 35.

16. Wróbel, S.; Przybylo, M.; Stepięń, E.; J. Clin. Med. 2019, 8, 368.

17. National Cancer Institute; Drugs Approved for Melanoma, available at https://www.cancer.gov/about-cancer/treatment/ drugs/melanoma, accessed in July 2021.

18. do Vale, J. A.; Lima, G. D. A.; Almeida, A. A.; Teixeira, R. R.; Neves, M. M. In Horizons in Cancer Research, vol. 77; Watanabe, H. S., ed.; Nova Science Publishers: Nova York, USA, 2020.

19. Gupta, A.; Gomes, F.; Lorigan, P.; Melanoma Manage. 2017, $4,125$.

20. Harvey, A. L.; Drug Discovery Today 2008, 13, 894.

21. Harvey, A. L.; Edrada-Ebel, R.; Quinn, R. J.; Nat. Rev. Drug Discovery 2015, 14, 111.

22. Thomford, N. E.; Senthebane, D. A.; Rowe, A.; Munro, D.; Seele, P.; Dzobo, A. M. K.; Int. J. Mol. Sci. 2018, 19, 1578.

23. Koparde, A. A.; Doijad, R. C.; Magdum, C. S.; In Natural Products in Drug Discovery; Intechopen: London, UK, 2019.

24. Chinembiri, T. N.; du Plessis, L. H.; Gerber, M.; Hamman, J. H.; du Plessis, J.; Molecules 2014, 19, 11679.

25. Alqathama, A.; Prieto, J. M.; Nat. Prod. Rep. 2015, 32, 1170. 26. Newman, D. J.; Cragg, G. M.; J. Nat. Prod. 2016, 79, 629.

27. De, P.; Baltas, M.; Bedos-Belval, F.; Curr. Med. Chem. 2011, $18,1672$.

28. Lima, G. D. A.; Rodrigues, M. P.; Mendes, T. A. O.; Moreira, G. A.; Siqueira, R. P.; da Silva, A. M.; Vaz, B. G.; Fietto, J. L. R.; Bressan, G. C.; Neves, M. M.; Teixeira, R. R.; Toxicol. In Vitro 2018, 53, 1.

29. Dheer, D.; Singhi, V.; Shankar, R.; Bioorg. Chem. 2017, 71, 30.

30. Agalave, S. G.; Maujan, S. R.; Pore, V. S.; Chem. - Asian J. 2011, 6, 2696.

31. Xu, Z.; Zhao, S.-J.; Liu, Y.; Eur. J. Med. Chem. 2019, 183, 111700 .

32. Liu, X.; Luo, J.; Kong, L.; Nat. Prod. Commun. 2011, 6, 851.

33. de Araújo-Vilges, K. M.; de Oliveira, S. V.; Couto, S. C. P.; Fokoue, H. H.; Romero, G. A. S.; Kato, M. J.; Romeiro, L. A. S.; Leite, J. R. A.; Kuckelhaus, S. A. S.; Pharm. Biol. 2017, 55, 1601.

34. Phuwaspraisiran, P.; Puksasook, T.; Jong-Aramruang, J.; Kokpol, U.; Bioorg. Med. Chem. Lett. 2008, 18, 4956.

35. Gaikwad, N.; Nanduri, S.; Madhavi, Y. V.; Eur. J. Med. Chem. 2019, 181, 111561.

36. Moreira, G. A.; Lima, G. D. A.; Siqueira, R. P.; Barros, M. V. A.; Adjanohoun, A. L. M.; Santos, V. C.; Barbosa, E. A. A.; Loterio, R. K.; de Paiva, J. C.; Gonçalves, V. H. S.; Viol, L. C. S.; Marques, E. S. A.; Júnior, A. S.; Almeida, M. R.; Fietto, J. L.
R.; Neves, M. M.; Ferreira, R. S.; Teixeira, R. R.; Bressan, G. C.; Toxicol. Appl. Pharmacol. 2018, 356, 214.

37. do Vale, J. A.; de Souza, A. P. M.; Lima, G. D. A.; Gonçalves, V. H. S.; Moreira, G. A.; Barros, M. V. A.; Pereira, W. L.; Lazaroni e Merchid, N. C.; Fietto, J. L. R.; Bressan, G. C.; Teixeira, R. R.; Neves, M. M.; Anticancer Drugs 2020, 31, 718.

38. Neises, B.; Steglich, W.; Angew. Chem., Int. Ed. 1978, 17, 522.

39. Kolb, H. C.; Finn, M. G.; Sharpless, K. B.; Angew. Chem., Int. Ed. 2001, 40, 2004.

40. Rostovtsev, V. V.; Green, L. G.; Fokin, V. V.; Sharpless, K. B.; Angew. Chem., Int. Ed. 2002, 41, 2596.

41. Torn申e, C. W.; Christensen, C.; Meldal, M.; J. Org. Chem. 2002, 67, 3057.

42. Singh, M. S.; Chowdhury, S.; Koley, S.; Tetrahedron 2016, 72, 5257.

43. Borgati, T. F.; Alves, R. B.; Teixeira, R. R.; de Freitas, R. P.; Perdigão, T. G.; da Silva, S. F.; dos Santos, A. A.; Bastidas, A. J. O.; J. Braz. Chem. Soc. 2013, 24, 953.

44. Sivakumar, K.; Xie, F.; Cash, M.; Long, S.; Barnhill, H. N.; Wang, Q.; Org. Lett. 2004, 24, 4603.

45. Reis, W. J.; Moreira, P. O. L.; Alves, R. B.; Oliveira, H. H. M.; Silva, L. M.; Varotti, F. P.; Freitas, R. P.; Curr. Top. Med. Chem. 2018, 18, 1475.

46. Dunagin, M. C.; Torborg, S. R.; Torre, E. A.; Emert, B.; Krepler, C.; Beqiri, M.; Sproesser, K.; Brafford, P. A.; Xiao, M.; Eggan, E.; Anastropoulos, J. N.; Vargas-Garcia, C. A.; Singh, A.; Nathanson, K. L.; Herlyn, M.; Raj, A.; Nature 2017, 546, 431.

47. Sova, M.; Zizac, Z.; Stankovic, J. A. A.; Prijatelj, M.; Turk, S.; Jurani, Z. D.; Mlinari -Rascan, I.; Gobec, S.; J. Med. Chem. 2013, 9, 633.

48. Yang, Y.; Zhang, Y.; Li, N.; J. Ethnopharmacol. 2019, 236, 129.

49. Romaguera, J. E. In Oncologic Imaging: A Multidisciplinary Approach; Rohren, E. M.; Erasmus, J. J.; Szklaruk, J.; Vining, D.; Sandler, C. M.; Kaur, H.; Hagemeister, F. B.; Madewell, J. E.; Raval, B.; Gladish, G., eds.; Elsevier Saunders: Philadelphia, USA, 2012.

50. Li, Y.; Zhang, G.; Cancer Biol. Med. 2017, 14, 348.

51. Hunke, M.; Martinez, W.; Kashyap, A.; Bokoskie, T.; Pattabiraman, M.; Chandra, S.; Anticancer Res. 2018, 8, 4469.

52. Gray-Schopfer, V.; Wellbrock, C.; Marais, R.; Nature 2007, $445,851$.

53. Balasas, T.; Callaghan, J.; Coombes, R. C.; Evans, J.; Hall, J. A.; Kinrade, S.; Jones, D.; Jones, P. S.; Jones, R.; Marshall, J. F.; Panico, M. B.; Shaw, J. A.; Steeg, P. S.; Sullivan, M.; Tong, W.; Westwell, A. D.; Ritchie, J. W. A.; Nat. Rev. 2019, 16, 185.

54. Niero, E. L.O.; Machado-Santelli, G. M.; J. Exp. Clin. Cancer Res. 2013, 32, 31.

55. Rosel, D.; Fernandes, M.; Veselý, P.; Heneberg, P.; Cermák, V.; Petruželka, L.; Kumar, S.; Sanz-Moreno, V.; Brábek, J.; Trends Cancer 2017, 3, 391. 
56. Yen, G.-C.; Chen, Y.-L.; Sun, F.-M.; Chiang, Y.-L.; Lu, S.-H.; Weng, C.-J.; Eur. J. Pharm. Sci. 2011, 44, 281.

57. Tsai, C.-M.; Yen, G. C.; Sun, F. M.; Yang, S. F.; Weng, C. J.; Mol. Pharmaceutics 2013, 10, 1890.

58. Almeida, A. A.; Lima, G. D. A.; Eiterer, M.; Rodrigues, L. A.; do Vale, J. A.; Zanatta, A. C.; Bressan, G. C.; de Oliveira, L. L.; Leite, J. P. V.; Planta Med., in press, DOI: 10.1055/a-1395-9046.

59. Siqueira, R. P.; Barbosa, E. A. A.; Polêto, M. D.; Righetto, G. L.; Seraphim, T. V.; Salgado, R. L.; Ferreira, J. G.; Barros, M. V. A.; de Oliveira, L. L.; Laranjeira, A. B. A.; Almeida, M. R.; Júnior, A. S.; Fietto, J. L. R.; Kobarg, J.; de Oliveira, E. B.;
Teixeira, R. R.; Borges, J. C.; Yunes, J. A.; Bressan, G. C.; PLoS One 2015, 10, e0134882.

60. Rasband, W. S.; ImageJ, version 1.49; U. S. National Institutes of Health, Bethesda, Maryland, USA, 2015.

61. Microsoft Excel, version 16.0; Microsoft Company, Redmond, WA, USA, 2016.

62. GraphPad Prism, version 6.01; GraphPad Software, Inc.; Software Mackiey, San Diego, California, USA, 2012.

Submitted: May 31, 2021 Published online: August 3, 2021 